\title{
Anxiety and Depression Symptoms, Self-Esteem and Body Image Among Patients with Gynecological Cancers: A Cross-Sectional Study
}

\author{
Jinekolojik Kanserli Hastalarda Anksiyete ve Depresyon Semptomları, Benlik Saygısı ve Beden Algısı: \\ Kesitsel Bir Çalıșma
}

\author{
Mehmet Fatih Üstündağ', Halil Özcan², Ece Yazla ${ }^{3}$, Yüksel Kıvrak ${ }^{4}$ Esat Fahri Aydın², Mehmet Yılmaz ${ }^{5}$ \\ ${ }^{1}$ Erenköy Rub ve Sinir Hastallklarn Hastanesi, Psikiyatri Kliniği, İstanbul; ${ }^{2}$ Atatürk Üniversitesi Tip Fakültesi, Psikiyatri Anabilim \\ Dal, Erzurum; ${ }^{3}$ Hitit Üniversitesi Tip Fakültesi, Psikiyatri Anabilim Dal, Çorum; ${ }^{4}$ Kafkas Üniversitesi Tip Fakültesi, Psikiyatri \\ Anabilim Dal, Kars; ${ }^{S}$ Atatürk Üniversitesi T⿰р Fakültesi, Kadın Hastalıkları ve Doğum Anabilim Dalı, Erzurum, Türkiye
}

\begin{abstract}
Aim: Gynecological cancers are among the most important health problems of women, with high rates of morbidity and mortality. These patients also have high rates of anxiety and depression symptoms which can affect the quality of life, self-care, self-esteem, body image, adherence, response to treatment and prognosis of the cancer. This study aimed to investigate the anxiety and depression symptoms, self-esteem and body image among patients with gynecological cancers.
\end{abstract}

Material and Method: In this study, anxiety and depression symptoms, self-esteem, body image satisfaction, and the effect of cancer on these parameters were investigated in eighty-one patients with gynaecological cancer who underwent surgery and have been taking chemotherapy currently. After obtaining the informed consent, a socio-demographic data form, Hospital Anxiety and Depression Scale (HADS), Body Image Scale (BIS) and Coopersmith SelfEsteem Scale (CSES) were applied to all participants.

Results: HADS-anxiety score was positively correlated with HAD depression score $(p<0.001)$ and negatively correlated with CSES $(p \leq 0.01)$ score. HADS-depression score was negatively correlated with BIS score $(p<0.01)$. HADS-anxiety score predicted the decrease in self-esteem weakly. HADS-depression score predicted the decrease in self-esteem and deterioration in body image as close to statistically significant. Increased symptoms of anxiety and depression as well as declined self-esteem and impaired body image were observed in patients treated for gynecological cancers.

Conclusion: In patients with gynecological cancers, the existence of possible anxiety and depression symptoms, impairment in selfesteem and body image should be screened; if detected, the treatment should be performed for the health of the patients.

Key words: cancer; gynecology; anxiety; depression

Ece Yazla, Hitit Üniversitesi Çorum Eğitim ve Araştırma Hastanesi Bahçelievler, Camlık Cd. No: 2, 19200 Merkez/Corum 19200 Corum - Türkiye,

Tel.05362644770Email.eceyazla@yahoo.com

Geliş Taribi: 17.07.2016 • Kabul Taribi: 28.07.2017

\section{ÖZET}

Amaç: Jinekolojik kanserler yüksek morbidite ve mortalite ile kadınların en önemli sağlık sorunlarından biridir. Bu hastalar aynı zamanda hayat kalitelerini, öz bakımlarını, benlik saygılarını, beden algılarını uyumlarını, tedaviye yanıtlarını ve kanser prognozlarını etkileyebilen yüksek oranlarda anksiyete ve depresyon semptomlarına sahiptirler. Bu çalıșma jinekolojik kanserli hastalarda anksiyete ve depresyon semptomlarını, benlik saygısını ve beden algısını araștırmayı amaçlamıștır.

Materyal ve Metot: Bu çalıșmada cerrahi operasyon geçiren ve halen kemoterapi almakta olan 81 jinekolojik kanserli hastada anksiyete ve depresyon semptomları, benlik saygısı, beden algısı memnuniyeti ve kanserin bu parametreler üzerine etkisi araștırıldı. Aydınlatılmıș onam formu alındıktan sonra tüm katılanlara birer sosyodemografik bilgi formu, Hastane Anksiyete ve Depresyon Ölçeği (HAD), Beden Algısı Ölçeği (BAÖ) ve Coopersmith Benlik Saygısı Ölçeği uygulandı (CBSÖ).

Bulgular: HAD Anksiyete skoru, HAD Depresyon skoru ile pozitif yönde $(p<0,001)$ ve CBSÖ skoru ile negatif yönde $(p \leq 0,01)$ ilișkiliydi. $H A D$ Depresyon skoru BAÖ skoru ile negatif yönde ilișkiliydi. $H A D$ anksiyete skoru ile benlik saygısındaki azalmayı zayıf olarak öngördü. HAD Depresyon skoru benlik saygısındaki azalmayı ve beden algısındaki bozulmayı istatistiksel olarak anlamlıya yakın olarak öngördü. Jinekolojik kanserler için tedavi edilmiș hastalarda artmıș anksiyete ve depresyon semptomları gibi azalmıș benlik saygısı ve bozulmuș beden algısı gözlendi.

Sonuç: Jinekolojik kanserli hastalarda olası anksiyete ve depresyon semptomlarının, bozulmuș benlik saygısının ve beden algısının varlığı takip edilmelidir. Eğer varlıkları tespit edilirse hastaların sağı̆̆̆ için tedavi uygulanmalıdır.

Anahtar kelimeler: kanser; jinekoloji, anksiyete; depresyon 


\section{Introduction}

Cancer is a group of diseases that commonly leads to death if undiagnosed early and untreated, and is responsible for $25 \%$ of deaths in developed countries ${ }^{1}$. Gynecological cancers are one of the most common cancers in a woman's life and have high morbidity and mortality rates ${ }^{2}$. Cancers are also commonly associated with psychiatric disorders ${ }^{3}$. The most common psychiatric disorders in cancer patients include adjustment disorder, anxiety and depression ${ }^{4}$. Depression may affect the quality of life, self-care, adherence to the treatment as well as the severity, course and treatment response in cancer patients ${ }^{1,3,5,6}$. The incidence of depression in cancer patients has been reported to range from $4.5 \%$ to as high as $58 \%$ with the risk factors for depression as a result of previous psychiatric disorders, low self-esteem, emotional stress and lack of emotional support ${ }^{5-7}$. Anxiety and depression has been reported to increase the possible disease symptoms and to have a negative impact on the quality of life ${ }^{8}$. Individuals with cancer representing symptoms of anxiety and depression have decreased coping skills and social interaction and support, reducing the performance for fighting against the disease and, indirectly, adversely affecting the quality of life, increasing the duration and cost of hospitalization ${ }^{9-12}$. Therefore, the diagnosis and treatment of psychiatric disorders and associated factors in cancer patients will increase the treatment adherence and quality of life ${ }^{13}$.

Self-esteem is defined as the respect of a person for herself/himself because of self-value and confidence. The decreased self-esteem found in the cancer patients possesses a significant problem for these patients ${ }^{14,15}$. Individuals caring and recognizing their bodies are concerned in their health and vice versa. However, it is of great importance for cancer patients to pay attention to their health and to come for regular follow-up visits because of the long-term nature of the treatment and for the follow-up of the disease.

Body image is an important component of self-esteem and mental health throughout a person's life and it is associated with self-acceptance, social self-confidence and becoming popular and attractive to the opposite $\operatorname{sex}^{16,17}$. In cases where the body integrity is disrupted due to the treatment of cancer (for instance, in breast cancer), it has been reported that self-esteem decreases and psychological problems increase ${ }^{18}$.

In this study we aimed to explore the socio-demographic characteristics, the presence and severity of possible anxiety and depression symptoms, self-esteem and body image as well as relationship of all these factors with each other. Results of the present study will increase the awareness of patients, their relatives as well as the health policy makers about the factors like mental problems and their predictors like low self-esteem or unlikable body image which may give harm to treatment success of gynaecological cancers. Early diagnosis of those mental problems and application of the suitable psychiatric treatment will help to increase the quality of life by making the cancer management easier for patients who have gynecological cancers.

\section{Material and Method}

The first 81 volunteer patients who received chemotherapy with the diagnosis of gynecological cancers in the Outpatient Chemotherapy Unit of Atatürk University Medical Faculty General Hospital during the determined time for the study were included in the study.

After obtaining the informed consent and respecting patient privacy, a socio-demographic data form including the data about age, gender, marital status, educational level, cancer type, previous and current therapies, and previous and current psychiatric problems as well as the Hospital Anxiety and Depression Scale (HADS), Coopersmith Self-Esteem Scale and Body Image Scale were administered to the patients. The ethical approval for the study was obtained from Ataturk University Medical Faculty ethical comittee.

\section{Hospital Anxiety and Depression Scale (HADS)}

This is a self-reported scale consisting of totally 14 items with 7 items for depression symptoms and 7 items for anxiety symptoms ${ }^{19}$. Each item is scored between 0 and 3. The aim of the scale is identifying the group at risk by screening anxiety and depression symptoms in individuals with a physical disease rather than making a diagnosis. Validity and reliability of the Turkish version of the Scale have been established with a cut-off value of 10 for anxiety subscale and 7 for depression subscale. These cut-off values have been suggested to have a sensitivity of $55 \%$ for the diagnosis of anxiety disorder and major depression ${ }^{20}$.

\section{Body Image Scale (BIS)}

This scale with a former name of Body Cathexis Scale (BCS) has been developed in 1953 by Secard and 
Jurard $^{21}$. The scale is used to assess the satisfaction of the individual from 40 separate organs or body parts (such as arms, face and hair) or from their function (such as level of sexual function). The Turkish version of the scale consists of 40 items in 5-point Likert type. The most negative expression is scored as 1 and the most positive expression is scored as 5 points. The possible lowest and highest total scores are 40 and 200, respectively. Turkish validity and reliability of the scale has been established with the increasing scores indicating the increased satisfaction of the individual from his/her body parts or body functions ${ }^{22}$. Cut-off value has been suggested as 135 points for the scale with defining the individuals with a score of $<135$ as having a low body image. The scale has been suggested to be used particularly in studies on depression.

\section{Coopersmith Self-Esteem Scale (CSES)}

The scale has been developed in 1967 for use in several age groups and particularly in adults ${ }^{23}$. The scale consists of 25 items responded as "like me" or "unlike me". The total score ranges from 0 and 100 with the higher scores indicating increased self-esteem. Turkish validity and reliability of the scale have been established ${ }^{24}$.

\section{Statistical Analysis}

Some socio-demographic data frequencies, and mean and standard deviations for these socio-demographic data were determined. Moreover, Pearson correlation analysis was used for the relationship of associated socio-demographic data with HADS, BIS and CSES scores. Logistic regression analysis was used to investigate the effects of symptoms of anxiety and depression on body image and self-esteem. All statistical analyses were performed by using SPSS 20.0 packet program with considering $\mathrm{p}<0.05$ as statistical significance level.

\section{Results}

Of the 81 participants, 73 were married, 1 was divorced, 1 was single and 6 were widowed. Only 7 participants were employed and the remaining were housewives. The type of cancer was endometrial cancer in 46, ovarian cancer in 23, cervical cancer in 11 and metastasis of the gastrointestinal cancer to genital organs in 1 patient. Five patients had a previous treatment history for the same cancer. Five patients were already under radiotherapy treatment. Eight patients had co-morbidities such as hypertension, diabetes mellitus and rheumatic disease, and were receiving the medications related to these diseases. Of the participants, 10 had a previous psychiatric problem (depression in 5, anxiety disorder in 3, psychotic disorder in 1 , obsessive-compulsive disorder in 1, trichotillomania in 1 , vaginismus in 1 ) with 2 patients reporting more than one problem. Six patients were already using psychotropic drugs. The age, educational level and the scores of HADS, BIS and CSES are shown in Table 1.

In the present study, age and educational level was not associated with HADS, BIS and CSES scores. On the other hand, there was a positive association between HADS-anxiety scores and HADS depression scores $(\mathrm{r}=0.529 ; \mathrm{p}<0.001)$ and a negative association between HADS-anxiety scores and CSES scores $(\mathrm{r}=$ $0.432 ; \mathrm{p} \leq 0.05)$. HADS-depression score was negatively associated with BIS score $(r=-0.315 ; \mathrm{p}<0.01)$. In the light of available literature data and clinical observations as well as the significant association between HADS-anxiety scores and CSES scores and between HADS-depression scores and BIS scores, the effects of anxiety and depression symptom scores-the clinical variables that may affect the CSES and BIS scores-on self-esteem and body image were analysed by means of logistic regression analysis with the enter method.

Table 1. The age, educational level and the scores of HADS, BIS and CSES

\begin{tabular}{lcccc}
\hline & $\mathrm{N}$ (number) & Minimum & Maximum & Mean \pm standard deviation \\
\hline Age & 81 & 27 & 75 & $51.2 \pm 9.6$ \\
Educational level (years) & 81 & 0 & 16 & $8.1 \pm 2.1$ \\
HADS-anxiety sub-score & 81 & 0 & 19 & $7.6 \pm 4.1$ \\
HADS-depression sub-score & 81 & 0 & 17 & $7.2 \pm 3.5$ \\
BIS score & 81 & 74 & 198 & $145.2 \pm 26.3$ \\
CSES score & 81 & 32 & 96 & $67.4 \pm 19.3$ \\
\hline
\end{tabular}


In the first method, when the dependent variable was HADS-anxiety score and the predictive variables were BIS and CSES scores, the cut-off point of 10 and over for HADS-anxiety score resulted in 1.06-times increase in self-esteem $(p=0.947 ; p<0.05)$. In the second model, when the dependent variable was HADSdepression score and the predictive variables were BIS and CSES scores, the cut-off point of 7 and over for HADS-depression score was close to significant decrease in self-esteem $(\mathrm{P}=0.954 ; \mathrm{p}=0.075)$ and in a near-significant increase in impairment of body image $(\mathrm{p}=0.962 ; \mathrm{p}=0.62)$.

\section{Discussion}

In the present study, mean HADS-anxiety score was $7.6 \pm 4.1$ and mean HADS-depression score was $7.2 \pm 3.5$ in 81 patients receiving treatment for various gynecological cancers. Previous studies have reported the lifetime prevalence and monthly prevalence of depression in women as $10-25 \%$ and $4.1-4.6 \%$, respectively ${ }^{25,26}$. On the other hand, lifetime prevalence of anxiety in women has been found as $30 \%{ }^{27}$. In the present study, 5 patients had a previous depression diagnosis and 3 patients had a previous anxiety diagnosis as well as 4 and 2 patients were already under followup for depression and anxiety, respectively. Therefore, HADS is not a diagnostic tool, the cut-off points of 10 for anxiety subscale and 7 for depression subscale had a sensitivity of $55 \%$, which suggests that some patients with anxiety and depression sub-scores over the cutoff points may be experiencing anxiety and depression symptoms. The patients with a score over the cut-off point in anxiety and/or depression sub-scores including the patients with previous or current diagnosis of depression or anxiety-referred to psychiatry outpatient clinic if they desire.

Mean BIS score for the participants was $145.2 \pm 26.3$. By considering the previously reported cut-off point of 135 and the possible maximum score of 200 , it can be suggested that some patients had a low body image ${ }^{22,28}$. This finding also suggests that gynecological cancers may deteriorate the body image in patients as reported in previous studies ${ }^{18}$. In the present study, mild deterioration in the body image might result from inadequate number of study population or from the fact that gynecological cancers usually affect the invisible internal organs that are not visible in social environments and by other people, patients with gynecological cancers may have body image deterioration less than expected.
Furthermore, because the patients recently diagnosed and treated for gynecological cancers were included in the present study, it is possible that these patients have not yet experienced the long-term effects of the disease such as chronic histological and anatomical disorders related to the disease and/or treatment, and weight loss, and thus the body image deteriorated less than expected. Moreover, there may be also several other factors affecting the body image but could not be measured in the present study.

Self-esteem score was found to be $67.4 \pm 19.3$ in the present study. By considering that previous studies regarded the cut-off point as $65^{22,28}$ and that the maximum possible score is 100 , self-esteem can be suggested to decrease in patients with gynecological cancers, as suggested in previous studies on cancer patients ${ }^{14}$. The mild decrease in self-esteem found in the present study might result from the inadequate number of study population or from the fact that these patients were diagnosed and treated recently; the long-term effects of the gynecological cancers on self-esteem could not be assessed. Moreover, there may be also several other factors affecting the self-esteem but could not be measured in the present study.

In previous studies on the factors affecting the quality of life in patients with gynecological cancers, although giving inconsistent results, the socio-demographic variables (age, educational level, marital status, etc.) were suggested to be associated with anxiety and depression symptoms, body image and self-esteem ${ }^{29,31}$. However, results of the present study did not support these findings. This might be the result of the inadequate number of study population and the fact that socio-demographic factors may not have primary deterministic role on these variables.

In the present study, HADS-depression score was significantly negatively associated with BIS, HADSanxiety and CSES scores. The logistic regression analysis showed that HADS-anxiety score slightly predicts the decrease in self-esteem, while HADS-depression score affect self-esteem and body image close to the significant level. These results suggest that anxiety and depression symptoms in patients with gynecological cancers may be associated with the decrease in self-esteem and body image and that these factors may be associated with each other. Similarly, in a previous study about obese people, depression symptoms were found to be negatively associated with self-esteem and body image $^{28}$. The inadequate number of study participants 
might result in the lack of association between these variables in the present study.

Major limitations of the present study were the inadequate number of study participants, the cross-sectional nature of the study and the lack of a control group. The study included only gynecological cancer patients who are taking chemotherapy in hospital. Also other potential factors those might be effecting depression and anxiety symptoms, and self-esteem and body image could not be investigated. However, the investigated factors may change during the life and during the course of the existing disease ${ }^{3}$. Moreover, some patients in the study group had received treatment for mental disorders previously. Thus, the anxiety and depression symptoms as well as the decreased self-esteem and body image found in the study participant might be present even before the gynecological cancer.

In conclusion, identification of the mental disorders including anxiety and depression symptoms commonly seen in patients with gynecological disorders and of the deteriorations in self-esteem and body image as well as the correction of all these associated factors (drug treatment for anxiety and depression symptoms, surgical aesthetic interventions for the deterioration of body image, and psychotherapeutic techniques for all symptoms) are important in these patient groups.

\section{References}

1. Jemal A, Siegel R, Xu J, Ward E. Cancer statistics. CA Cancer J Clin 2010;60(5):277-300.

2. American Cancer Society Cancer Facts and Figures. Annual Report. California Division and Public Health Ins 2007: www. cancer. org/docroot/CRI.

3. Berard RM. Depression and anxiety in oncology: the psychiatrist's perspective. J Clin Psychiatry 2001;62(8):58-63.

4. Kutlu R, Çivi S, Börüban MC, Demir A. Depression and the Factors Affecting the Quality of Life in Cancer Patients Selçuk Üniv Tip Derg 2011;27(3):149-53.

5. Manne SL, Andrykowski MA. Are psychological interventions effective and accepted by cancer patients? II. Using empirically supported therapy guidelines to decide. Ann Behav Med 2006;32(2):98-103.

6. Andrykowski MA, Manne SL. Are psychological interventions effective and accepted by cancer patients? I. Standards and levels of evidence. Ann Behav Med 2006;32(2):93-7.

7. Seven M, Akyüz A, Sever N, Dinçer Ş. [Studying the Physical and Psychological Symptoms of Patients with Cancer] TAF Prev Med Bull 2013;12(3):219-24.
8. Lee JI, Kim SH, Tan AH, Kim HK, Jang HW, Hur KY, et al. Decreased health-related quality of life in disease-free survivors of differentiated thyroid cancer in Korea. Health Qual Life Outcomes 2010;15(8):101.

9. Valente SM, Saunders JM. Diagnosis and treatment of major depression among people with cancer. CancerNurs 1997;20(3):168-77.

10. Norum J, Wist EA. Quality of Life in Survivors of Hogkins' Disease. Quality of Life Research 1996;5(3);367-74.

11. Teixeira RJ, Pereira MG. Psychological morbidity, burden, and the mediating effect of social support in adult children caregivers of oncological patients undergoing chemotherapy. Psychooncology 2013;22(7):1587-93.

12. D’Antonio LL, Long SA, Zimmerman GJ, Peterman AH, Petti GH, Chonkich GD. Relationship between quality of life and depression in patients with head and neck cancer. Laryngoscope 1998;108(6):806-11.

13. Hardman A, Maguire P, Crowther D. The recognition of psychiatric morbidity on a medical oncology ward. J Psycosom Res 1989;33(2):235-9.

14. Ozkan B, Mentes S, Ozturk A, Soyuer S. Effects of Follow-up by Phone Interview and Anger Management Training Provided to Patients with Breast Cancer Undergoing Radiotherapy on Levels of Self-Esteem, Anger and Depression. International Journal of Hematology and Oncology 2014;4(24):260-9.

15. Cam O, Gümüs AB. Breast cancer screening behavior in Turkish women: Relationships with health beliefs and self-esteem, bodyperception and hopelessness. Asian Pac J Cancer Prev 2009;10(1):49-56.

16. Harter S. Developmental differences in the nature of selfrepresentations: implications for the understanding, assessment and treatment of maladaptive behaviour. Cognitive Therapy and Research 1990;14(2):113-42.

17. Ramachandran VS, Brang D, McGeoch PD, Rosar W. Sexual and food preference in apotemnophilia and anorexia: interactions between 'beliefs' and 'needs' regulated by twoway connections between body image and limbic structures. Perception 2009;38(5):775-7.

18. Gümüş AB, Çam O. Relationships Between Early Diagnosis Attitudes In Cervical Cancer Of Women And Levels Of SelfEsteem, Body Perception And Hopelessness. Nobel Med 2011;7(3):46-52.

19. Zigmond AS, Snaith PR. The hospital anxiety and depression scale. Acta Psychiatr Scand 1983;67:361-70.

20. Aydemir O. Validity and Reliability of Turkish Version of Hospital Anxiety and Depression Scale. Türk Psikiyatri Dergisi 1997;8:280-7.

21. Secord PF, Jourard SM The appraisal of body-cathexis: bodycathexis and the self. J Consult Psychol 1953;17(5):343-7.

22. Hovardaoğlu S. Body Image Scale 3P Dergisi 1993;1:26.

23. Coopersmith S. Self Esteem Inventories. Consulting Psychologist Press: California; 1967. 
24. Turan N, Tufan B. Coopersmith benlik saygısı envanteri'nin geçerlik-güvenirlik çalışması. [The study of reliability and validity for the Coopersmith sef-esteem scale] 23. National conference of psychiatry and neurological Sciences: İstanbulTürkiye; 1987.

25. Moses-Kolko EL, Roth EK. Antepartum And Postpartum Depression: Healthy Mom, Healthy Baby. J Am Med Womens Assoc 2004;59:181-91.

26. Myers JK, Weissman MM, Tischler GL, Holzer CE 3rd, Leaf PJ, Orvaschel $\mathrm{H}$, et al. Six month prevalence of psychiatric disorders in three communities 1980 to 1982. Arch Gen Psychiatry 1984;41:959-70.

27. Schiffer RB. Psychiatric Disorders In Medical Practice Cecil Texbook of Medicine, 21th ed, Philadelphia: W. B. Saunders Company 2000;2047-56.
28. Pinar R. Depression, Self-Esteem and Body Image in Obese People: a Comparative Study C. Ü. Hemşirelik Yüksekokulu Dergisi 2002;6(1):30-41.

29. Tahmasebi M, Yarandi F, Eftekhar Z, Montazeri A, Namazi H. Quality of life in gynecological cancer patients. Asian Pac J Cancer Prev 2007;8(4):591-2.

30. Kizilc1 $S$. The factors effected quality of life of people with cancer and their relatives. C. Ü. Hemşirelik Yüksekokulu Dergisi 1999;3(2):18-25.

31. Mishel M, Sorenson DS. Uncertainty in gynecological cancer: A test of the mediating functions of mastery and coping Nurs Res 1991;40(3):167-71. 